\title{
MENDESKRIPSIKAN PROSES MENGAJAR MENGGUNAKAN KOMIK DALAM MEMBACA TEKS NARASI KELAS IX
}

\author{
Endah Wulandari \\ Universitas Muhammadiyah Surakarta (UMS) Jawa Tengah, Indonesia \\ Email:a320180041@student.ums.ac.id
}

\begin{tabular}{ll}
\hline INFO ARTIKEL & ABSTRAK \\
\hline Diterima & Penelitian ini difokuskan pada penggunaan komik sebagai media \\
25 Oktober 2021 & pembelajaran membaca pada siswa kelas IX SMP. Masalah \\
Direvisi & dalam penelitian ini adalah motivasi siswa dalam membaca \\
05 November 2021 & khususnya teks naratif rendah dan nilai mereka dalam beberapa \\
Disetujui & tes rata-rata rendah. Mereka masih bingung untuk memahami isi \\
15 November 2021 & cerita, terbukti dari nilai ulangan mereka rata-rata rendah dalam \\
\hline Kata Kunci: & soal membaca yaitu 65,7 dan mereka tidak dapat menceritakan \\
pengajaran & kembali isi cerita secara singkat. Menggunakan komik dalam \\
membaca; & pembelajaran, siswa terbantu untuk memahami isi cerita yang \\
komik; & dibacanya. Metode dalam penelitian ini menggunakan penelitian \\
teks naratif & kualitatif dengan istilah studi kasus. Subjek penelitian ini adalah \\
& siswa kelas IX SMP. Jumlah peserta adalah 3 siswa. Hasil \\
& penelitian menunjukkan bahwa pelaksanaan pembelajaran \\
& membaca dengan menggunakan media komik memberikan \\
& manfaat bagi siswa, hal ini ditunjukkan dari 2 dari 3 siswa atau \\
& 66,6\% siswa setuju penggunaan komik sebagai media \\
& pembelajaran. Berdasarkan hasil angket, komik memberikan \\
& manfaat dalam pengajaran membaca terhadap peningkatan \\
& keterampilan membaca siswa. Terungkap bahwa 2 dari 3 siswa \\
& atau 66,6\% siswa memberikan respon positif setelah pelaksanaan \\
& kegiatan, namun hanya 33,3\% siswa yang menunjukkan \\
& ketidakjelasan akan manfaatnya. Penggunaan komik juga dapat \\
& dikombinasikan dengan teknik lain untuk mengembangkan \\
pemahaman materi dan membuat siswa senang, tertarik, dan & \\
antusias selama proses belajar mengajar. Selain itu, hasil \\
penelitian menunjukkan bahwa komik membantu siswa dalam \\
memahami isi cerita.
\end{tabular}

\section{ABSTRACT}

This study focused on the use of comics as a medium for learning to read in class IX SMP. The problem in this research is that students' motivation in reading especially narrative texts is low and their scores in some tests are low on average. They are still confused to understand the content of the story, as evidenced by their low average score on reading, which is 65.7 and they cannot retell the story briefly. By using comics in learning,

\begin{tabular}{ll}
\hline How to cite: & Wulandari, E., (2021) Mendeskripsikan Proses Mengajar Menggunakan Komik dalam Membaca \\
& Teks Narasi Kelas IX. Jurnal Syntax Admiration 2(11). https://doi.org/10.46799/jsa.v2i11.340 \\
E-ISSN: & $2722-5356$ \\
Published by: & Ridwan Institute
\end{tabular}


students are helped to understand the content of the stories they read. The method in this study uses qualitative research with the term case study. The subjects of this study were students of class IX SMP. The number of participants is 3 students. The results showed that the implementation of reading learning using comics media provided benefits for students, this was shown from 2 out of 3 students or $66.6 \%$ of students agreed to use comics as learning media. From the results of the questionnaire, comics provide benefits in teaching reading to improve students' reading skills. It was revealed that 2 out of 3 students or $66.6 \%$ of students gave a positive response after the implementation of the activity, but only $33.3 \%$ of students showed that the benefits were unclear. The use of comics can also be combined with

Keywords: teaching read; comic; narrative text other techniques to develop understanding of the material and make students happy, interested, and enthusiastic during the teaching and learning process. In addition, the results showed that comics helped students in understanding the content of the story.

\section{Pendahuluan}

Menurut (Makhrus, 2018) Mendefinisikan gaya belajar sebagai cara di mana individu memahami dan memproses informasi dalam situasi belajar. Dia berpendapat bahwa gaya belajar preferensi adalah salah satu aspek gaya belajar, dan mengacu pada pilihan satu pembelajaran situasi atau kondisi di atas yang lain. (Asmara \& Nindianti, 2019) mendefinisikan gaya belajar sebagai: pendekatan umum yang digunakan siswa dalam memperoleh bahasa baru atau dalam mempelajari mata pelajaran lain. Sementara itu, (Pamungkas et al., 2018) menyatakan bahwa belajar gaya adalah karakteristik kognitif, efektif, sosial dan fisiologis perilaku yang berfungsi sebagai indikator bagaimana siswa memahami informasi, berinteraksi dengan orang lain, dan menanggapi situasi dalam proses belajar. Sederhananya, belajar gaya adalah cara karakteristik di mana seorang individu memperoleh, merasakan, dan memproses informasi.

(Gani, 2019) gaya belajar adalah "alami, kebiasaan, dan cara yang paling disukai untuk menyerap, memproses, dan menyimpan informasi baru dan keterampilan”. Dia mengklasifikasikan gaya sebagai mayor, minor, atau dapat diabaikan. Jurusan lebih diutamakan gaya belajar, minor adalah gaya belajar di mana peserta didik masih dapat berfungsi tetapi mereka tidak berkinerja baik sebagai yang utama, dan diabaikan berarti mereka mungkin mengalami kesulitan belajar dalam gaya belajar itu. Selain itu, (Hidayah \& Ulva, 2017) telah mengembangkan instrument disebut Perceptual Learning Style Preference Questionnaire (PLSPQ) khusus untuk Pembelajar bahasa asing bahasa Inggris berdasarkan bagaimana siswa belajar paling baik menggunakan bahasa mereka persepsi sendiri. Selanjutnya model gaya belajar dan angket oleh Reid menjadi fokus penelitian ini. Ada beberapa pertimbangan untuk memilih model gaya belajar dan angket oleh Reid sebagai fokus penelitian ini. Ini mudah untuk menafsirkan, mudah 
melaporkan skala, penilaian diri, mudah dikelola, memiliki keandalan dan validitas yang didukung oleh penelitian.

Membaca adalah salah satu keterampilan berbahasa yang paling penting yang harus dikembangkan di dalam dan di luar kelas. Ini juga salah satu cara paling umum untuk mendapatkan informasi. Menurut Harmer, pembaca menggunakan sejumlah keterampilan khusus ketika membaca dan keberhasilan mereka dalam memahami isi dari apa yang mereka lihat sangat bergantung pada luas pada keterampilan khusus ini. Keterampilan membaca adalah: keterampilan preduktif, mengekstraksi spesifik gambar, mendapatkan gambaran tertentu, mengekstrak informasi rinci dan pola wacana, mengurangi makna dari konteks. Selanjutnya, Yekovich di Westwood menyatakan bahwa terampil membaca adalah kemampuan yang sangat kompleks yang melibatkan banyak proses komponen. Pendeknya, belajar membaca adalah proses yang kompleks yang bergantung pada mempelajari keterampilan tertentu (Lutfifati, 2011).

Membaca adalah langkah pertama dalam memperoleh pengetahuan. Membaca adalah hal yang sangat penting masalah yang tidak hanya tentang kesenangan tetapi juga kebutuhan; alat dasar pendidikan.

Membaca bukanlah pelajaran yang mudah, karena dalam mempelajarinya pembaca harus menemukan ide-idenya dari sebuah teks berdasarkan sudut pandang penulis. Ur menyatakan bahwa membaca berarti "membaca dan memahami". Dia juga menyatakan beberapa asumsi tentang sifat membaca yang kita perlu memahami dan memecahkan kode huruf untuk membaca kata-kata; kita perlu memahami semua kata-kata untuk memahami makna sebuah teks; semakin banyak simbol (huruf dan kata) dalam sebuah teks, semakin lama waktu yang dibutuhkan untuk membacanya; kita kumpulkan: makna dari apa yang kita baca; pemahaman kita tentang teks berasal dari pemahaman kata-kata yang terdiri.

Kalayo (Setyawan, 2018) menyatakan bahwa membaca adalah proses interaktif yang berlangsung antar pembaca dan teks, sehingga menghasilkan pemahaman. Teks menyajikan huruf, kata, kalimat dan paragraf yang menyandikan makna. Pembaca menggunakan pengetahuan, keterampilan, dan strategi untuk tentukan apa artinya. Jadi membaca adalah komunikasi antara pembaca dan pembaca teks tertulis. Pembaca harus menggunakan keterampilan mereka untuk memahami isi teks.

Richards menyatakan bahwa pemahaman berarti identifikasi yang dimaksudkan arti komunikasi tertulis atau lisan. Pemahaman adalah proses membuat arti kata, kalimat, dan teks terhubung. Pemahaman harus menjadi fokus utama mengajar anak-anak membaca dan bukan sesuatu yang harus ditekankan hanya setelah anak-anak memiliki belajar bagaimana memecahkan kode dan mengidentifikasi kata-kata.

Membaca sebagai salah satu keterampilan berbahasa memiliki peranan yang sangat penting. Siswa harus memahami bacaan untuk tujuan tertentu namun membutuhkan metode yang praktis dan sesuai. Gagasan tersebut didukung oleh 
fakta bahwa membaca kini telah menjadi bagian dari kehidupan sehari-hari. Membaca tidak dapat dipisahkan dari aktivitas sehari-hari. Siswa membaca berbagai macam bahan tertulis seperti koran, majalah, novel, buku akademik dan sebagainya. Melalui membaca siswa dapat memperoleh banyak informasi, pengetahuan, kesenangan bahkan pemecahan masalah. Membaca dapat dilihat sebagai proses interaktif antara pembaca dan teks yang mengarah pada kelancaran atau kelancaran membaca (Mahendra et al., 2021).

(Hendratmoko et.al., 2017) menyatakan bahwa membaca adalah keterampilan penting bagi siswa bahasa Inggris sebagai bahasa asing. Bagi sebagian besar siswa ini, ini adalah keterampilan yang paling penting untuk dikuasai untuk memastikan keberhasilan tidak hanya dalam belajar bahasa Inggris, tetapi juga dalam belajar di kelas konten mana pun di mana membaca bahasa Inggris diperlukan.

Dengan memperkuat keterampilan membaca bahasa Inggris, siswa akan membuat kemajuan besar dan perkembangan di semua bidang pembelajaran lainnya. Membaca berguna untuk pemerolehan bahasa. Siswa juga mendapat lebih banyak efek positif dari membaca. Dengan membaca mereka mendapatkan pengetahuan kosa kata, tentang ejaan dan tulisan mereka.

Menurut (Rozie, 2018) Siswa yang membaca di kelas bawah tidak perlu melelahkan diri untuk mencoba memahami teks komik, yang memungkinkan mereka untuk rileks, suatu sikap yang tentu saja memfasilitasi pembelajaran. Karena bahasa Inggris adalah bahasa asing, dapat dimengerti bahwa sebagian besar siswa menghadapi kesulitan dalam memahami sebuah teks bacaan. Kesulitan tersebut terkadang membuat siswa frustasi. Mereka kehilangan motivasi untuk belajar bahasa Inggris sehingga mereka tidak menikmati belajar bahasa Inggris. Bahasa Inggris sebagai bahasa asing dianggap sulit dipelajari terutama dalam membaca karena bahasa Inggris bukanlah bahasa ibu dari para siswa (Savitri, 2019).

(Naldi \& Susanti, 2018) menyatakan bahwa tujuan dari semua guru yang berkomitmen adalah untuk memfasilitasi pembelajaran. Hal ini sangat membutuhkan upaya kreatif dari guru bahasa Inggris untuk melakukan proses belajar-mengajar. Agar lebih menarik guru harus menciptakan banyak cara untuk menjelaskan materi pelajaran sehingga dapat dipahami dengan baik oleh siswa.

Salah satu hal yang dihadapi guru bahasa Inggris adalah kesulitan untuk mengajar bahasa Inggris sebagai bahasa asing karena keterbatasan waktu, media yang terbatas, sumber yang terbatas dan bagaimana mendorong siswa untuk menemukan minat mereka dan menikmati belajar bahasa Inggris terutama membaca (Beckman \& Diamond, 1984).

(Cahyaningrum et al., 2019) menjelaskan bahwa sangat penting bagi guru untuk memilih dan menyeleksi bahan dan media bacaan. Guru harus memperhatikan kompetensi siswa dan juga kurikulum, karena kurikulum merupakan standar kompetensi dalam pembelajaran di sekolah. Jika guru telah menemukan materi yang tepat, mereka harus memilih media yang baik juga, karena 
media yang baik akan mendukung proses belajar mengajar. (Pada et al., n.d.) menyatakan, ada tiga macam media yang kita ketahui. Yaitu media audio, visual, dan audio visual. Media yang dapat kita dengar adalah audio, dan media yang dapat kita lihat adalah visual, sedangkan media yang dapat kita dengar dan lihat disebut audio visual. Sebagai seorang guru, penting untuk menentukan media yang tepat ketika mengajar siswa (Purwanitasari, 2020).

Komik adalah serangkaian gambar yang digambar berdekatan, biasanya disusun secara horizontal, yang dirancang untuk dibaca sebagai narasi atau urutan kronologis (Encyclopedia Britannica). Komik dapat didefinisikan sebagai "serangkaian gambar di dalam kotak yang menceritakan sebuah cerita" (Juniarto \& Fahri, 2019). Menurut (Mukti \& Soedjoko, 2021), komik adalah sastra gambar. Komik adalah suatu komposisi atau gambar-gambar lain dalam urutan yang terarah dan mempunyai tujuan untuk menyampaikan informasi dan tanggapan visual dalam pandangan. Menurut Mallia (Savitri, 2019), komik adalah teks naratif yang diceritakan melalui rangkaian gambar-gambar yang diteruskan dari satu urutan ke urutan berikutnya dan disertai dialog dan/atau teks di dalam gambar. Kosakata adalah keseluruhan simbol visual. (Rosita, 2018) menyatakan bahwa penggunaan komik dapat memperoleh kepercayaan pembaca, memulai proses membangun kepercayaan diri mereka dan menawarkan pengalaman membaca yang sukses.

Dalam penelitian ini, tujuan dari penelitian ini adalah untuk menganalisis proses pengajaran membaca dengan menggunakan komik pada keterlibatan siswa sekolah menengah pertama teks-teks tersebut. Dalam penelitian ini, peneliti mencoba mencari media terbaik yang diharapkan dapat meningkatkan atau meningkatkan pemahaman membaca siswa khususnya dalam teks naratif.

Permasalahan yang melatarbelakangi penelitian ini adalah motivasi siswa dalam membaca dan pemahaman mereka terhadap isi cerita masih rendah, hal ini terlihat dari wawancara dengan beberapa siswa bahwa mereka merasa bosan dengan bacaan. Sedangkan nilai siswa tergolong rendah dengan nilai rata-rata 65,7.

Fokus penelitian ini adalah pada pemahaman membaca siswa terutama pada pemahaman informasi rinci dari teks. Berdasarkan permasalahan tersebut, peneliti menawarkan buku komik untuk menyelesaikan permasalahan tersebut. Dengan dikombinasikan dengan strategi lain, peneliti menggunakan komik untuk membantu siswa dalam memahami isi cerita. Penelitian ini bertujuan untuk mengetahui bagaimana komik dapat meningkatkan kemampuan membaca siswa khususnya pada pemahaman isi cerita dan meningkatkan motivasi membaca siswa.

Penggunaan media yang sesuai diharapkan dapat membantu guru untuk membuat instruksi yang bermakna dan juga memotivasi siswa untuk meningkatkan kemampuan membaca mereka. Media yang sesuai dengan tujuan penelitian adalah komik. Hal ini dikarenakan banyak orang, khususnya pelajar menyukai komik. Sebagian besar anak-anak dan remaja bahkan dewasa menyukai komik karena visualnya, atraktif, humoris, dan daya tariknya secara keseluruhan (Kane, 2017). 
Alasan kedua, komik adalah media menarik yang menyajikan gambar dan dialog. Dialog dan gambar dalam komik dapat memudahkan siswa untuk menemukan ide tentang apa yang akan mereka tulis. Komik Strip juga merupakan media yang baik. Penggunaan Komik dapat menghindari kebosanan siswa karena tampilan yang menarik.

\section{Metode Penelitian}

\section{Metode Pelaksanaan}

Metode penelitian adalah kualitatif. Bodgan dan Tylor mendefinisikan pendekatan kualitatif sebagai prosedur penelitian yang menghasilkan data deskriptif berupa ucapan atau kata-kata verbal atau non verbal dari objek yang diamati. Stake menyatakan bahwa pendekatan kualitatif menyajikan informasi mengenai status fenomena saat ini dan diarahkan pada penentuan situasi seperti yang ada pada saat penelitian. Meskipun pada dasarnya semua analisis kualitatif didasarkan pada isi, analisis isi khususnya berlaku untuk studi kasus ini, karena wawancara, observasi, dan dokumen mengungkapkan pola dan tema yang terkait erat dengan pertanyaan penelitian Merriam.

Metodologi analisis hanya melibatkan pengkodean data mentah dan kemudian membuat kategori yang sesuai berdasarkan ide-ide yang muncul. Karena saya mendekati studi kasus dengan mempertimbangkan hipotesis umum dan siap untuk diuji, saya membatasi konstruksi kategori hanya pada tema-tema yang berhubungan langsung dengan penggunaan komik. Meskipun konteks terkait juga muncul, (yaitu, penggunaan teknologi dan jenis penilaian), saya menghilangkan bidang studi tersebut karena ada banyak data yang dapat diterapkan secara langsung untuk menambang.

\section{Subjek dan Tempat Penelitian}

Subjek penelitian adalah guru Bahasa Inggris dan 3 siswa kelas IX. Tempat dari penelitian ini adalah di Rumah.

\section{Sumber Data}

Sumber data penelitian ini diambil dari kegiatan belajar mengajar di rumah ketika siswa mendapatkan bagian membaca dalam teks naratif pada bab memahami gagasan utama.

\section{Teknik Pengumpulan Data}

Pengumpulan data penelitian ini menggunakan wawancara, observasi, dan angket. Metode pengumpulan data yang paling dasar dari penelitian ini adalah observasi untuk mendapatkan sumber data. Untuk mendukung penelitian ini, peneliti juga menggunakan instrumen pendukung untuk mengumpulkan data, yaitu berupa lembar observasi, wawancara dan angket. Lembar observasi digunakan untuk mengumpulkan data yang berkaitan dengan proses belajar mengajar di kelas. Wawancara digunakan untuk beberapa tujuan, yaitu: (1) Mengetahui informasi unik yang tidak terjadi dalam kegiatan kelas, (2) Mengumpulkan banyak informasi dari banyak orang, (3) Menemukan hal-hal yang tidak dapat diamati oleh peneliti. Angket digunakan untuk memperoleh data tentang sikap siswa terhadap pelaksanaan 
pembelajaran aktif. Ini terdiri dari sepuluh nomor dan diberikan kepada siswa setelah proses belajar mengajar.

\section{Analisis Data}

Analisis data adalah suatu sistem untuk menyusun data dan menyajikannya kepada orang lain. (Miles \& Huberman, 1994) memandang bahwa analisis data kualitatif terdiri dari reduksi data, penyajian data, dan penarikan kesimpulan.

Reduksi data adalah tahapan mengolah data "mentah" agar siap untuk dianalisis. Bentuk proses analisis data adalah memilih, menyederhanakan, memfokuskan, meringkas, mengkode, mengurutkan, atau bahkan membuat klaster tema.

Penyajian data adalah proses mendemonstrasikan data baik dalam bentuk teks naratif, matriks, grafik, jaringan atau bagan. Dalam konteks penelitian ini, data yang ditampilkan berupa kutipan percakapan, interaksi kelas dan hasil wawancara. Kedua langkah di atas, mulai dari mereduksi data hingga menampilkan data, diterapkan setiap kali peneliti memperoleh data dari satu sesi topik. Berdasarkan kegiatan tersebut, peneliti membuat kesimpulan analisis dan memusatkan perhatian pada pengumpulan data selanjutnya. Kesimpulan ditulis berdasarkan analisis lembar observasi, hasil wawancara, dan dokumentasi yang berkaitan dengan penelitian dengan cara menghitung dan meringkas data.

\section{Hasil dan Pembahasan}

Isu penggunaan komik dalam proses belajar mengajar adalah bagaimana kaitannya dengan kegunaannya. Terkait dengan praktik nyata dalam pembelajaran, efektivitas penggunaan komik ditunjukkan oleh (Setyowati, 2010), Mereka melakukan penelitian pada tingkat pendidikan yang sama tetapi aspek dan genre teks yang berbeda. Ahmad Kurniadi melakukan penelitiannya tentang pemahaman bacaan, sedangkan Purwanitasari dan Lutfifati melakukan penelitiannya tentang menulis. Temuan Ahmad Kurniadi menunjukkan bahwa penerapan komik dapat meningkatkan pemahaman membaca teks naratif siswa kelas delapan SMPN 8 Bandar Lampung. Temuan Purwanitasari menunjukkan bahwa komik strip berhasil meningkatkan kemampuan siswa kelas VIII SMPN 2 Malang dalam menulis teks recount.

Sementara itu, temuan Lutfifati mendukung penelitian Purwanitasari dengan memberikan bukti bahwa komik strip merupakan strategi yang baik untuk memecahkan masalah menulis yang dihadapi oleh siswa kelas delapan SMPN 9 Malang, khususnya dalam menulis teks naratif.

Pertanyaan pertama yang ingin saya sampaikan melalui studi kasus adalah: bagaimana keterlibatan siswa dipengaruhi oleh penggunaan komik tambahan di kelas tingkat atas? Apa yang saya temukan adalah bahwa keterlibatan siswa jelas merupakan bidang minat yang paling terpengaruh dalam keseluruhan studi. Mereka terbantu dalam memahami isi cerita. Meski mereka tidak tahu arti kalimat, dengan melihat gambar di komik, mereka bisa menebak apa yang dibicarakan cerita. Tingkat keterlibatan siswa meningkat secara dramatis di setiap kelas selama komik dibaca dan didiskusikan, dan dalam beberapa kasus, peningkatan keterlibatan siswa berlanjut di seluruh unit dan di 
luar kesimpulannya. Siswa lebih antusias dalam proses membaca. Mereka fokus pada proses belajar mengajar. Siswa mengaku senang dengan pembelajaran menggunakan komik. Para guru dan magang bersatu dan tegas dalam keyakinan mereka bahwa keterlibatan siswa dipengaruhi secara positif oleh penggunaan komik, dan mereka semua menimbulkan kejutan pada dampak yang jelas pada siswa mereka. Ketika para siswa pertama kali menyadari bahwa mereka akan mendengar dan melihat komik, reaksi awal mereka beragam. Karena pertanyaan usia (dibahas sebelumnya), beberapa siswa mengerang, memutar mata, atau membuat pernyataan seperti, "Kamu benar-benar tidak akan membacakan kami buku anak-anak!” Orang lain yang kurang peduli dengan citra diri merespons secara fisik dan verbal, menampilkan perilaku seperti tepuk tangan dan anak seperti seruan kebahagiaan. Namun, sebagian besar hanya diam dan mengungkapkan keingintahuan ringan melalui perhatian pada aktivitas tersebut. Tetapi setelah guru menjelaskan metode baru, mereka dapat memahami dan menerimanya. Sebelum menggunakan komik sebagai media, mereka biasanya bosan ketika guru meminta mereka membaca beberapa bacaan, tetapi setelah guru menggunakan komik, mereka mulai tertarik.

Pada proses belajar mengajar, karena pertama kali diajar dengan media komik, sebagian siswa masih asyik sendiri. Mereka kurang memperhatikan kegiatan pembelajaran. Guru kemudian mengkombinasikan media dengan strategi pembelajaran kooperatif sehingga siswa mulai tertarik.

Ada masalah selama proses belajar mengajar. Guru kesulitan menemukan materi yang sesuai dengan kurikulum. Namun masalah tersebut bisa diselesaikan dengan browsing beberapa materi di internet.

Selain itu hasil belajar mengajar menggunakan media komik, siswa merasa tertantang dengan materi tersebut. Siswa merasa penasaran dengan cerita dan makna kalimat pada setiap gambar, sehingga mereka mencoba mencari maknanya di kamus. Dengan menemukan arti dari kalimat-kalimat dalam kamus, itu membuat siswa meningkatkan kosa kata mereka. Jadi, kemampuan mereka dalam memahami informasi detail teks meningkat.

Selama wawancara pasca studi kasus, para guru dan pekerja magang mengungkapkan beberapa kekhawatiran tentang komik yang menciptakan rasa menyenangkan di kelas, tetapi para siswa tidak keberatan. Mereka sering mengatakan bahwa mereka senang mendengar dan melihat buku, dan banyak tawa mengiringi pelajaran, termasuk dari para guru. Tema lain yang muncul adalah kecurigaan otomatis siswa dan reaksi negatif terhadap "pekerjaan" yang dirasakan. Saya sering memperhatikan siswa menunda memulai tugas atau meminta bantuan pada tugas sebelum mengerahkan upaya awal. Ini adalah aspek penghindaran kerja atau penolakan kerja, dan hal ini umum terjadi di ruang kelas sekolah menengah.

Akhirnya, saya ingin memahami apakah penggunaan komik berdampak pada penguasaan materi siswa. Dengan kata lain, apakah tujuan pembelajaran guru tercapai? Meskipun tidak sejelas hubungan yang jelas dengan keterlibatan, pembelajaran siswa 
terpengaruh, terutama di antara ELL dan siswa yang cenderung tidak berhasil dalam tugas membaca. Saat saya mengevaluasi data.

\section{Pembahasan Bagaimana Guru Menerapkan Komik dalam Pembelajaran Membaca pada Siswa Kelas IX SMP}

Berdasarkan temuan penelitian ini, terbukti bahwa penggunaan komik sebagai media pembelajaran membaca di SMP merupakan salah satu cara yang tepat untuk mengajarkan teks naratif dan memberikan kontribusi yang bermanfaat dalam meningkatkan kemampuan membaca siswa. Membawa metodologi instruksional baru ke kelas merangsang refleksi guru tentang praktik mereka yang pasti meningkatkan budaya kelas dan menempatkan guru di samping siswa dalam peran belajar. Berbagi komik dengan siswa tidak terkecuali. Daftar berikut menjelaskan beberapa kesadaran yang diperhatikan guru tentang diri mereka sendiri selama studi kasus:

a. Perlunya meningkatkan hubungan siswa.

b. Keinginan untuk menyelidiki pengalaman membaca awal siswa, apakah positif atau negative.

c. Kekritisan pembelajaran scaffolding.

d. Motivasi untuk mencoba metode pembelajaran baru.

e. Rasa bersalah dan kritik diri ketika pelajaran tidak efektif, bahkan jika hanya untuk satu siswa.

f. Pentingnya pengajaran reflektif.

g. Membawa kreativitas.

h. Kebutuhan untuk peka terhadap gaya belajar individu siswa, Saya Perlunya sering menggunakan penyelenggara tingkat lanjut.

i. Pentingnya instruksi langsung, eksplisit.

j. Kesadaran akan kompleksitas pengalaman remaja.

Media ini diimplementasikan sebagai proses memahami teks dan sebagai konstruksi makna dari teks tertulis. Untuk pelajar EFL, pemahaman membaca adalah hal utama. Dengan membaca, siswa berusaha memahami arti kata atau kalimat. Dalam hal ini perlu strategi untuk membuat siswa tertarik untuk membaca. Penggunaan komik merupakan salah satu strategi untuk membuat siswa tertarik untuk membaca. Komik membantu siswa untuk memecahkan kode dan visualisasi informasi dan memberikan ilustrasi kepada siswa ketika mereka membaca. Komik membantu siswa memahami isi cerita, bahkan mereka tidak.

Banyak sekali komponen yang mendukung proses belajar mengajar. Komponen-komponen tersebut sering digunakan oleh guru untuk menyajikan pengajaran yang inovatif. Guru harus mempersiapkan materi sebelum mengajar. Materi yang harus disiapkan sebelum pembelajaran membaca adalah.

- RPP

- Bahan Bacaan

- Media Pembelajaran

- Formulir Penilaian 
Selain guru menggunakan media komik, guru juga memadukan dengan strategi pembelajaran kooperatif. Cara ini ditempuh agar siswa dapat diatur sesuai dengan rencana guru. Strateginya cocok dengan media komik.

\section{Diskusi Macam-Masalah Apa Saja yang Muncul Saat Pelaksanaan Pada Siswa Kelas IX SMP}

Berdasarkan temuan penelitian ini dengan mewawancarai guru terbukti bahwa penggunaan media komik dalam pengajaran membaca memiliki beberapa masalah yang muncul selama pelaksanaan. Data wawancara menunjukkan bahwa dibutuhkan lebih banyak waktu untuk mempersiapkan materi pembelajaran sebelum waktu dimulai. Misalnya, guru harus menyiapkan dan menemukan cerita atau komik yang sesuai dengan topik. Tapi itu bisa diselesaikan dengan browsing materi di internet.

Masalah selanjutnya adalah waktu yang tidak memadai. Guru harus mengatur waktu sedemikian rupa untuk menjelaskan materi. Namun masalah tersebut dapat diselesaikan dengan mengkombinasikan materi dengan strategi pembelajaran kooperatif.

\section{Diskusi Apa Tanggapan Siswa Terhadap Penerapan Pada Siswa Kelas IX SMP}

Berdasarkan hasil penelitian dengan memberikan angket kepada siswa, terbukti bahwa penggunaan media komik dalam pengajaran membaca memiliki respon yang positif. Hampir semua siswa merasa sangat antusias membaca teks, sangat termotivasi untuk membaca, dan merasa percaya diri dalam menjawab pertanyaan dalam membaca. Padahal pada saat pertama kali penerapannya mereka merasa seperti anak-anak. Studi ini mengungkapkan bahwa pengetahuan awal pembaca yang lemah membantu dan memotivasi pembaca jika mereka terbiasa dengan cerita dalam bahasa ibu mereka sebelum membaca cerita dalam bahasa kedua.

\section{Kesimpulan}

Setelah peneliti mengadakan penelitian, ia menyimpulkan penerapan komik dalam pengajaran membaca pada siswa SMP di SMP. Dengan hasil penelitian dan pembahasan, peneliti menawarkan beberapa saran. Saran ditujukan kepada guru dan peneliti selanjutnya. Bagi guru yang memiliki permasalahan yang sama dengan guru SMP disarankan untuk menggunakan komik sebagai media agar siswa merasa antusias dan aktif dalam proses membaca. Guru harus fokus pada penyusunan rencana pelajaran dan memilih materi yang sesuai dengan tingkat siswa. Hal penting yang harus dilakukan guru adalah memadukan materi dengan strategi pembelajaran kooperatif.

Peneliti selanjutnya, khususnya yang tertarik untuk menggunakan komik sebagai media dalam penelitiannya, disarankan untuk melakukan penelitian dalam pengajaran membaca teks naratif pada level yang berbeda. Selain itu, peneliti selanjutnya juga disarankan untuk melakukan penelitian tindakan dalam pengajaran membaca dengan menggunakan genre yang berbeda. 


\section{BIBLIOGRAFI}

Asmara, Y., \& Nindianti, D. S. (2019). Urgensi Manajemen Kelas Untuk Mencapai Tujuan Pembelajaran. Sindang: Jurnal Pendidikan Sejarah Dan Kajian Sejarah, 1 (1), 12-24. https://doi.org/10.31540/sdg.v1i1.192. Google Scholar

Beckman, J., \& Diamond, J. (1984). Picture Books in the Classroom: The Secret Weapon for the Creative Teacher. English Journal, 73 (2), 102-104. Google Scholar

Cahyaningrum, A. D., AD, Y., \& Asyhari, A. (2019). Pengaruh Model Pembelajaran Quantum Teaching Tipe Tandur Terhadap Hasil Belajar. Indonesian Journal of Science and Mathematics Education, 2 (3), 372-379.

https://doi.org/10.24042/ijsme.v2i3.4363. Google Scholar

Gani, A. A. (2019). Interaksi Antara Pemanfaatan Media Pembelajaran Dan Gaya Belajar Terhadap Hasil Belajar Ips Terpadu. Civicus: Pendidikan-PenelitianPengabdian Pendidikan Pancasila Dan Kewarganegaraan, 6 (2), 82. https://doi.org/10.31764/civicus.v6i2.677. Google Scholar

Hendratmoko et.al. (2017). Tujuan Pembelajaran Berlandaskan Konsep Pendidikan Jiwa Merdeka Ki Hajar Dewantara. Jinotep, 3 (2), 152-157. Google Scholar

Hidayah, N., \& Ulva, R. K. (2017). Pengembangan media pembelajaran berbasis komik pada mata pelajaran ilmu pengetahuan sosial kelas IV MI Nurul Hidayah Roworejo Negerikaton Pesawaran. Jurnal Pendidikan Dan Pembelajaran Dasar, 4 (1), 34-46. Google Scholar

Juniarto, B. W., \& Fahri. (2019). Using Webtoon Comic as Media in Teaching Reading Narrative Text for Junior High School Students Bagus Wahyu Juniarto Abstrak. Retain, 7 (3), 153-160. Google Scholar

Kane, S. (2017). Literacy \& Learning: In the Content Areas. Routledge. Google Scholar

Lutfifati, N. I. (2011). Using Comic Strips To Improve The Eighth Grade Students'ability In Writing Narrative Texts At Smpn 9 Malang. Skripsi Jurusan Sastra Inggris-Fakultas Sastra UM. Google Scholar

Mahendra, E. R., Siantoro, G., \& ... (2021). Pengembangan Komik Pendidikan Sebagai Media Pembelajaran Dan Pengaruhnya Terhadap Motivasi Belajar Siswa. Jurnal Education ..., 9 (1), 279-284.

http://journal.ipts.ac.id/index.php/ED/article/view/2375. Google Scholar

Makhrus, M. (2018). Analisis Rencana Pelaksanaan Pembelajaran (Rpp) Terhadap Kesiapan Guru Sebagai "Role Model” Keterampilan Abad 21 Pada Pembelajaran Ipa Smp. Jurnal Penelitian Pendidikan IPA, 5 (1).

https://doi.org/10.29303/jppipa.v5i1.171. Google Scholar 
Miles, M. B., \& Huberman, A. M. (1994). Qualitative data analysis: An expanded sourcebook. sage. Google Scholar

Mukti, A. A. B., \& Soedjoko, E. (2021). Kemampuan Siswa pada Aspek Berpikir Kreatif Ditinjau dari Gaya Belajar Melalui Pembelajaran Problem Posing Berbasis Open-Ended Problem. PRISMA, Prosiding Seminar Nasional ..., 4, 26-36. https://journal.unnes.ac.id/sju/index.php/prisma/article/view/44955. Google Scholar

Naldi, F., \& Susanti, A. (2018). Pengaruh Model Pembelajaran Co-op Co-op terhadap Pemahaman Konsep Ditinjau dari Gaya Belajar Visual, Audio, Kinestetik Siswa Kelas VIII SMPN 43 Merangin. Edumatica: Jurnal Pendidikan Matematika, 8 (01), 23-35. https://online-journal.unja.ac.id/edumatica/article/view/4115. Google Scholar

Pada, J., Kelas, S., \& Smp, V. I. I. (n.d.). 1, 2 , 3. Google Scholar

Pamungkas, A. S., Mentari, N., \& Nindiasari, H. (2018). Analisis Kemampuan Berpikir Reflektif Siswa SMP Berdasarkan Gaya Belajar. Numerical: Jurnal Matematika Dan Pendidikan Matematika, 2 (1), 69.

https://doi.org/10.25217/numerical.v2i1.209. Google Scholar

Purwanitasari, L. (2020). Using comic strips to improve the ability of students of SMP Negeri 2 Malang in writing recount text. Skripsi Mahasiswa UM. Google Scholar

Rosita, L. (2018). Peran Pendidikan Berbasis Karakter Dalam Pencapaian Tujuan Pembelajaran Di Sekolah. Jurnal Ilmu Politik Dan Komunikasi, 8 (1). https://doi.org/10.34010/jipsi.v8i1.879. Google Scholar

Rozie, F. (2018). Persepsi Guru Sekolah Dasar Tentang Penggunaan Media Pembelajaran Sebagai Alat Bantu Pencapaian A. Latar Belakang Masalah Pendidikan yang sangat merupakan penting dan bagian tidak mandiri serta tanggung jawab kemasyarakatan dan ke bangsaan". Berdasarkan. Jurnal Pendidikan Dan Pembelajaran Sekolah Dasar, 5, 1-12. Google Scholar

Savitri, A. I. (2019). Strip Komik: Alat Bantu Pengajaran yang Menarik bagi Pembelajar Pemula dalam Kelas Percakapan. 188-197. https://doi.org/10.33810/274173. Google Scholar

Setyawan, F. H. (2018). The effectiveness of using comic in teaching reading narrative text. Jet Adi Buana, 3 (1), 67-75. Google Scholar 
Setyowati, A. (2010). Upaya Meningkatkan Kecerdasan Verbal Linguistik Anak Melalui Membaca Gambar Di Tk Pertiwi Dari Tahun 2009/2010 (Penelitian Tindakan Kelas Di Tk Pertiwi 1 Dari Kabupaten Sragen). Universitas Muhammadiyah Surakarta. Google Scholar

\section{Copyright holder: \\ Endah Wulandari (2021)}

First publication right:

Jurnal Syntax Admiration

This article is licensed under:

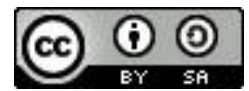

